\title{
Idiopathic intracranial hypertension: long-term follow-up and impact on patients' visual function with a literature review
}

\author{
Idiopatyczne nadciśnienie śródczaszkowe - efekty odległe, ze szczególną oceną wpływu \\ choroby na funkcje wzrokowe pacjentów
}

\author{
'Neurology Department, Copernicus PL, St. Adalbert Hospital, Gdańsk, Poland \\ ${ }^{2}$ Department of Neurological and Psychiatric Nursing, Medical University of Gdańsk, Poland \\ ${ }^{3}$ Ophthalmology Department, Copernicus PL, St. Adalbert Hospital, Gdańsk, Poland \\ ${ }^{4}$ Radiology Department, Copernicus PL, St. Adalbert Hospital, Gdańsk, Poland \\ Correspondence: Magdalena Kwaśniak-Butowska, Neurology Department, Copernicus PL, St. Adalbert Hospital, Jana Pawła II 50, 80-462 Gdańsk, Poland, tel.: +48 697 720 797, e-mail: magda.kwasniak@gmail.com \\ Magdalena Kwaśniak-Butowska, Oddział Neurologiczny, Szpital św. Wojciecha, al. Jana Pawła ll 50, 80-462 Gdańsk, tel.: + 48697 720 797, e-mail: magda.kwasniak@gmail.com
}

\begin{abstract}
Aim: The aim of the study was a long-term observation (particularly in terms of visual function) of patients hospitalised at the Neurology Department of St. Adalbert Hospital in Gdańsk, Poland, due to an episode of idiopathic intracranial hypertension. Material and methods: The Department's archives held records of 13 cases of idiopathic intracranial hypertension treated from 2007 to 2015. The retrospectively retrieved data concerned: age, sex, height, weight, comborbidities, symptoms of idiopathic intracranial hypertension, neurological abnormalities, fundoscopy findings, vision field, brain magnetic resonance findings, visual evoked potentials and employed treatment. Eleven patients reported for a follow-up examination, and 6 patients completed it. The patients were examined neurologically and ophthalmologically with fundoscopy, visual field test, visual acuity and visual evoked potentials. The results were compared with the disease history data. The follow-up period lasted 4-47 months. Results: Nine of 11 patients were females. In 2 of them, the initial diagnosis was revised, and 3 did not complete all procedures. Six patients were included in the analysis. The most common complain upon admission was headache and tunnel vision. Brain magnetic resonance imaging scans revealed changes characteristic of idiopathic intracranial hypertension in 5 patients. Therapeutic drainage of cerebrospinal fluid was performed in all the patients, and all of them were treated with acetazolamide. Visual disturbances (visual field loss or impaired visual evoked potentials) persisted in 3 patients. Significant risk factors for idiopathic intracranial hypertension in the analysed group were: female sex, increased body mass index and reproductive age. Permanent vision impairment was observed in patients who required more intensive treatment. Conclusion: Weight gain is a significant risk factor for poor outcome. Visual field assessment and fundoscopy seem to be superior than visual acuity in the monitoring of disease activity.
\end{abstract}

Keywords: idiopathic intracranial hypertension, visual evoked potentials, visual field loss, papilloedema, headache, long-term follow-up

Streszczenie

Cel: Celem pracy była długofalowa ocena stanu chorych, w szczególności funkcji wzrokowych, po przebyciu epizodu idiopatycznego nadciśnienia śródczaszkowego, hospitalizowanych na Oddziale Neurologicznym Szpitala św. Wojciecha w Gdańsku. Materiał i metody: W archiwum od 2007 do 2015 roku znaleziono 13 przypadków idiopatycznego nadciśnienia śródczaszkowego. Retrospektywnie, z dostępnych historii choroby, uzyskano informacje dotyczące: wieku, płci, wzrostu, wagi, obciążeń internistycznych, objawów idiopatycznego nadciśnienia śródczaszkowego, odchyleń w badaniu neurologicznym, badaniu dna oczu, pola widzenia, rezonansu magnetycznego mózgowia, wzrokowych potencjałów wywołanych oraz zastosowanej terapii. Na badanie kontrolne zgłosiło się 11 chorych, a 6 je ukończyło. Pacjentów zbadano neurologicznie oraz wykonano badanie ostrości wzroku, pola widzenia, dna oczu oraz wzrokowych potencjałów wywołanych. Otrzymane dane porównano z informacjami z historii choroby. Okres obserwacji wynosił 4-47 miesięcy. Wyniki: W grupie 11 chorych było 9 kobiet oraz 2 mężczyzn. U 2 kobiet podczas kontroli zmieniono rozpoznanie, 3 pacjentów nie ukończyło badania. Sześciu chorych włączono do dalszych analiz. Najczęściej zgłaszanym objawem przy przyjęciu na Oddział były bóle głowy oraz tunelowe zaburzenia w polu widzenia. W badaniu rezonansu magnetycznego mózgowia 5 chorych miało zmiany typowe 
dla idiopatycznego nadciśnienia śródczaszkowego. U wszystkich pacjentów wykonano terapeutyczny upust płynu mózgowo-rdzeniowego i włączono acetazolamid. U 3 pacjentów utrzymywały się zaburzenia funkcji wzrokowych (ubytki w polu widzenia lub nieprawidłowy wynik badania wzrokowych potencjałów wywołanych). Istotnymi czynnikami ryzyka rozwoju idiopatycznego nadciśnienia śródczaszkowego w badanej grupie były płeć żeńska, wzrost wskaźnika masy ciała oraz wiek reprodukcyjny. W badanej grupie przetrwałe zaburzenia widzenia wystąpiły u chorych wymagających intensywniejszego leczenia odwadniającego. Wnioski: Wzrost masy ciała jest istotnym czynnikiem pogarszającym rokowanie. Ocena dna oczu oraz badanie pola widzenia wydają się lepszymi parametrami do monitorowania aktywności choroby niż ocena ostrości widzenia.

Słowa kluczowe: idiopatyczne nadciśnienie śródczaszkowe, wzrokowe potencjały wywołane, ubytki w polu widzenia, obrzęk tarczy nerwu wzrokowego, ból głowy, długofalowa ocena

\section{INTRODUCTION}

$\mathrm{I}$ diopathic intracranial hypertension (IIH) is a condition in which the cerebrospinal fluid (CSF) pressure increases $>250 \mathrm{~mm} \mathrm{H}_{2} \mathrm{O}$ without any accompanying central nervous system pathologies (Friedman et al., 2013). It is a rare condition with an unclear aetiology. It most often affects obese fertile women. Vitamin A in the form of retinoic acid, corticosteroids, sex hormones, obstructive sleep apnoea, Addison's disease, polycystic ovary syndrome (PCOS), and tetracyclines may also be involved in IIH pathogenesis. Increased resistance to CSF outflow seems to be essential in the pathophysiology (McGeeney and Friedman, 2014). The most common clinical presentation involves visual disturbances (often chronic) and persistent headache which significantly decreases patients' quality of life (Bruce et al., 2016). The aim of this study was to analyse long-term follow-up (particularly visual function) of patients hospitalised due to an episode of IIH.

\section{MATERIAL AND METHODS}

The database of the Neurology Department of St. Adalbert Hospital in Gdańsk was searched for records of IIH patients from 2007 to 2015. Thirteen records were found, and the following data were extracted retrospectively: age, sex, height, weight, comorbidities, IIH symptoms and time of their onset, other neurological findings, dilated fundus examination, visual field examination (static or kinetic perimetry), brain magnetic resonance imaging (MRI), visual evoked potential (VEP), and the provided treatment. Although, except for one patient, all underwent a lumbar puncture proving elevated CSF opening pressure, the specific value was unavailable. Of the original 13 patients, 11 appeared for the follow-up visit during which the following examinations were conducted: a neurological examination and fundoscopy, visual field (static perimetry), Snellen visual acuity, and VEP. The patients signed informed consent.

\section{RESULTS}

Nine of the 11 patients were female and 2 were male. visit: one developed neuromyelitis optica spectrum disorder during the observation period, whereas in the other patient fundoscopy and OCT (optical coherence tomography) revealed optic nerve drusen mimicking papilloedema. Other 3 patients did not participate in all procedures. These 5 cases were not included in further analysis.

Upon admission, 5 out of 6 patients complained about headache and visual disturbances (3 reported tunnel vision, while 3 complained about visual acuity loss). The age range of the female patients was $22-50$ years, while male patients were $46-50$ years old, the average age was 36.1. In terms of IIH risk factors, 4 patients had increased body mass index (BMI) and 1 woman used oral contraceptives. The following coexisting illnesses were also noted: nicotine addiction, PCOS, hypertension, hyperlipidaemia, and iron deficiency anaemia, and possibly contributing medications, i.e. oral contraceptives (OC) (Tab. 1).

Fundoscopy findings and visual function upon admission and follow-up visit are compared in Tab. 2. Brain MRI scans revealed typical IIH changes in 5 patients (Figs. 1-3). Therapeutic drainage of $10-60 \mathrm{~mL}$ of CSF was performed in 6 patients, resulting in reduced headache within a week and later improvement in visual symptoms. All patients were treated with acetazolamide $(500 \mathrm{mg}-2 \mathrm{~g} /$ day for 2-24 weeks), one of whom was switched to topiramate $(100 \mathrm{mg} /$ day $)$. Three of those patients needed additional treatment with furosemide (Tab. 3).

The follow-up period lasted 4-47 months. In 2 females, a recurrence of IIH was noted within 12 months from the onset. The most common complaint during the follow-up was episodic migraine-type headache ( 2 of 4 patients with headache). BMI increased in 5 patients and was still abnormal in 4 cases. Visual disturbances (visual field loss or impaired VEP) persisted in 3 patients. Optic nerve sheath fenestration was performed in one female patient.

\section{DISCUSSION}

The well-known IIH risk factors, i.e. female sex, increased BMI and reproductive age (Mallery et al., 2014; Wall et al., 2014), appear to be significant also in the analysed group. Tab. 4 presents the results of a literature review regarding this topic. The main symptoms of the disease at the onset 


\begin{tabular}{|l|l|l|l|l|l|l|l|}
\hline $\begin{array}{l}\text { Patient } \\
\text { number/ } \\
\text { sex/age }\end{array}$ & BMI & Symptoms & Comorbidity/risk factors & $\begin{array}{l}\text { Symptoms } \\
\text { onset before } \\
\text { hospitalisation }\end{array}$ & Recurrence & $\begin{array}{l}\text { Follow-up } \\
\text { period } \\
\text { (months) }\end{array}$ & $\begin{array}{l}\text { BMI } \\
\text { (follow-up) }\end{array}$ \\
\hline 1/W/22 & 32.05 & $\begin{array}{l}\text { Headache, nausea, } \\
\text { visual acuity loss }\end{array}$ & $\begin{array}{l}\text { Depression, thrombocytopenia } \\
\text { treated with Encorton at the age of } 5\end{array}$ & 4 weeks & No & 41 & 34.05 \\
\hline 2/W/27 & 20.42 & $\begin{array}{l}\text { Headache, visual } \\
\text { acuity loss }\end{array}$ & PCOS, 0C & 7 weeks & No & 74 & 21.45 \\
\hline 3/M/50 & 26.26 & $\begin{array}{l}\text { Headache, tunnel } \\
\text { vision }\end{array}$ & $\begin{array}{l}\text { Hypertension, stomach ulcers, } \\
\text { clindamycin }\end{array}$ & 1 day & No & 20 & 27.42 \\
\hline 4/W/24 & 37 & $\begin{array}{l}\text { Headache, tunnel } \\
\text { vision }\end{array}$ & $\begin{array}{l}\text { Resection of the ovary, } \\
\text { microdiscectomy }\end{array}$ & 1 day & $\begin{array}{l}\text { Headache, visual field } \\
\text { loss, tinnitus, after } 4 \text { and } \\
59 \text { weeks from the onset }\end{array}$ & 16 & 40.9 \\
\hline 5/W/48 & 27 & $\begin{array}{l}\text { Headache, visual } \\
\text { acuity loss }\end{array}$ & $\begin{array}{l}\text { Chronic lower back pain syndrome. } \\
\text { Spinal cord stimulator }\end{array}$ & Unknown & $\begin{array}{l}\text { Headache, diplopia, } \\
\text { visual field and acuity } \\
\text { loss, tinnitus, after 3, } \\
19,\end{array}$ & 17 \\
\hline 6/M/46 & 24.86 & None from the onset & 29 \\
\hline W - woman; $\mathbf{M}-$ man. & None & Unknown & No & 54 \\
\hline
\end{tabular}

Tab. 1. Demographic and clinical data

\begin{tabular}{|c|c|c|c|c|c|c|c|c|c|}
\hline \multirow{3}{*}{$\begin{array}{l}\begin{array}{l}\text { Patient } \\
\text { number/ } \\
\text { sex/age }\end{array} \\
\text { 1/W/22 }\end{array}$} & \multicolumn{4}{|l|}{ Initially } & \multicolumn{5}{|c|}{ Follow-up } \\
\hline & \multirow{2}{*}{$\begin{array}{l}\begin{array}{l}\text { Fundus } \\
\text { R-L }\end{array} \\
P>P\end{array}$} & \multirow{2}{*}{$\begin{array}{l}\text { Visual field } \\
\mathrm{N}\end{array}$} & \multicolumn{2}{|c|}{ VEP: latency P100 R-L* } & \multirow{2}{*}{$\begin{array}{l}\begin{array}{l}\text { Fundus } \\
\text { R-L }\end{array} \\
\mathrm{N}-\mathrm{N}\end{array}$} & \multirow{2}{*}{$\begin{array}{l}\text { Visual field } \\
\text { - }\end{array}$} & \multirow{2}{*}{$\begin{array}{l}\text { Visual acuity } \\
\text { N }\end{array}$} & \multicolumn{2}{|c|}{ VEP: latency P100 R-L } \\
\hline & & & 96 & 94.5 & & & & 99.8 & 99 \\
\hline $2 / W / 27$ & P-P & $\begin{array}{l}\text { Central scotoma over } \\
30 \text { degrees for both } \\
\text { eyes }\end{array}$ & 163.8 & 148.8 & $\mathrm{~N}-\mathrm{N}$ & N & $\mathrm{N}$ & 99.3 & 94.8 \\
\hline $3 / M / 50$ & P-P & Bitemporal loss & 140 & 154.8 & $\mathrm{~N}-\mathrm{N}$ & N & N & 123.3 & 125.3 \\
\hline 4/W/24 & P-P & Tunnel vision & 99 & 94.8 & $\mathrm{~N}-\mathrm{N}$ & Blind spot enlargement & N & 96.3 & 94.5 \\
\hline $5 / W / 48$ & $P>P$ & Tunnel vision & 100.7 & 104.5 & $\mathrm{~N}-\mathrm{N}$ & $\begin{array}{l}\text { Significant peripheral } \\
\text { loss, the most severe } \\
\text { in the upper quadrants }\end{array}$ & $\begin{array}{l}\text { Vod } 0.2 \\
\text { Vos } 0.2\end{array}$ & 165 & 132.3 \\
\hline $6 / M / 46$ & P-P & - & 104.3 & 103.8 & $\mathrm{~N}-\mathrm{N}$ & $\mathrm{N}$ & N & 103.5 & 101.3 \\
\hline
\end{tabular}

Tab. 2. Comparison of fundoscopy findings and visual function upon admission and follow-up visit

in patients described in the literature were: headache, transient visual obscurations, pulsatile tinnitus, diplopia, and visual field loss. Obese women at childbearing age were at the greatest risk. Papilloedema and elevated intracranial pressure (ICP) were present. Visual field defect was usually mild and presented as glaucoma-like arcuate nerve fibre bundle loss, more common in the inferior hemifield. Other presentations were: isolated enlarged blind spot (without a contiguous nerve fibre bundle defect), normal hemifield, and diffuse field depression (Keltner et al., 2014; Rowe and Sarkies, 1998). In general, the outcome in the presented studies was good. The improvement of the visual status was observed in the majority of patients after typical treatment (D'Amico et al., 2014; NORDIC Idiopathic Intracranial Hypertension Study Group Writing Committee, 2014), and in perimetry, seen particularly in the nasal and pericecal areas (Wall et al., 2016).

In our study, permanent vision impairment was observed in patients requiring more intensive treatment, which correlates with the results observed by Wall et al. (2015) in 151 patients who were treated with acetazolamide for mild visual disturbances due to IIH. The time of onset before hospitalisation varied from 1 day to 7 weeks and did not influence the visual outcome. Other authors noted also that the severity of the final visual loss depends on initial VA (visual acuity) and MD (visual field mean deviation) 


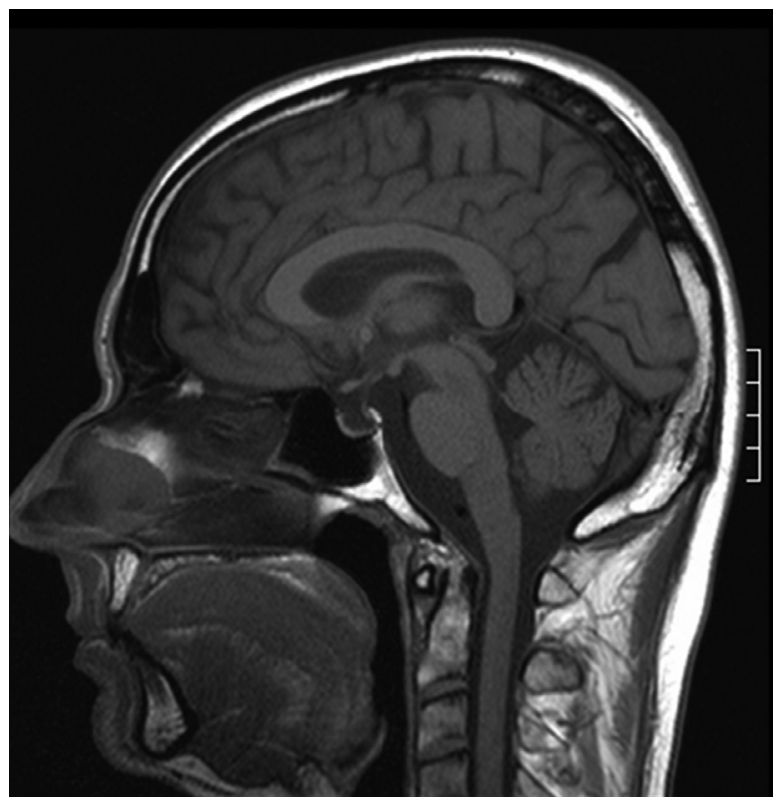

Fig. 1. Empty sella (Patient 6/M/46)

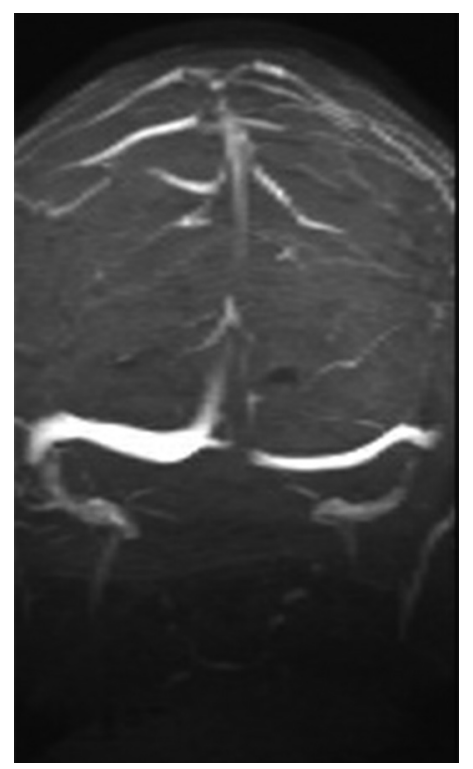

Fig. 2. Transverse sinus stenosis (Patient 5/W/48)

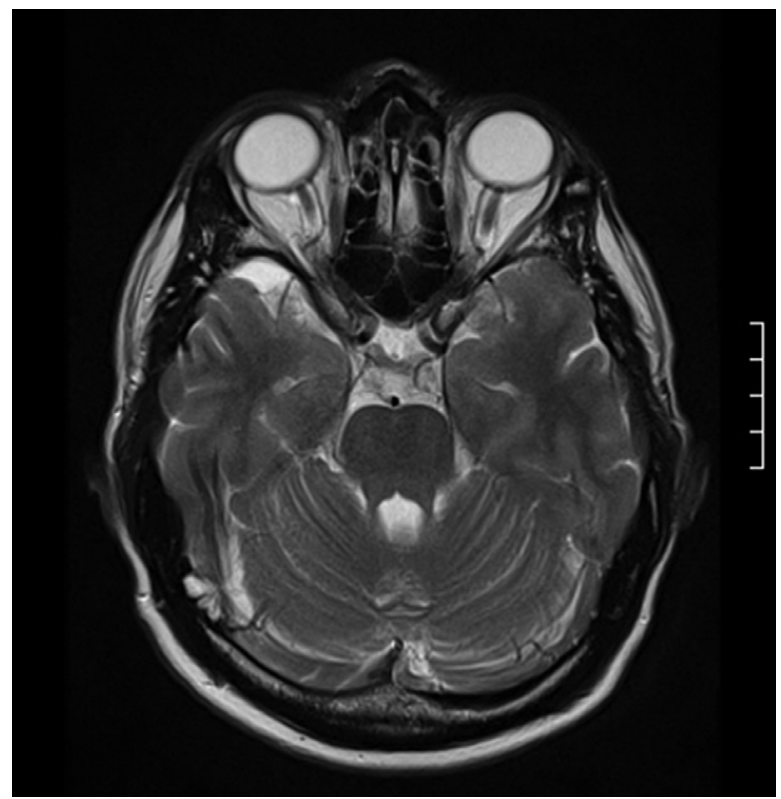

Fig. 3. Distention of the perioptic subarachnoid space (Patient $6 / M / 46)$

(if worse, it negatively influenced prognosis) (Agarwal et al., 2017; Rosenblatt et al., 2016). Weight gain was another risk factor for poor outcome (Chagot et al., 2017; Yri et al., 2012). High opening pressure and young age at onset were correlated with good clinical outcome in terms of headache in the study of Yri et al. (2014), but had no influence on final visual function.

Upon admission, our male IIH patients were older than females, a trend also noted by Bruce et al. (2009). Unlike in females, the most common early manifestation of IIH in males involves prolonged and gradual onset of visual disturbances. Therefore, males with IIH are more likely to wait before visiting a physician, thus the disease process is more advanced upon diagnosis, and the risk of permanent vision impairment is greater, which, however, was not observed in our group (Bruce et al., 2009).

Increased BMI is one of the main risk factors for $\mathrm{IIH}$ recurrence (Ko et al., 2011). The highest body mass increase noted in our sample was $10 \%$, and this patient

\begin{tabular}{|c|c|c|c|}
\hline $\begin{array}{c}\text { Patient number/ } \\
\text { sex/age }\end{array}$ & $\begin{array}{c}\text { CSF drainage } \\
(\mathbf{m L})\end{array}$ & MRI findings & Acetazolamide (mg/day) \\
\hline 1/W/22 & 10 & Distention of the perioptic subarachnoid space & 750 \\
\hline 2/W/27 & 40 & Distention of the perioptic subarachnoid space with the tortuous optic nerve & $1000+$ furosemide \\
\hline $3 / \mathrm{M} / 50$ & 55 & Distention of the perioptic subarachnoid space with the tortuous optic nerve & $1000+$ furosemide/topiramate (100 mg/day) \\
\hline 4/W/24 & 50 & Left transverse venous sinus stenosis & $2000+$ furosemide \\
\hline $5 / \mathrm{W} / 48$ & 60 & Empty sella, right transverse venous sinus stenosis, distention of the perioptic \\
subarachnoid space & 500 \\
\hline $6 / \mathrm{M} / 46$ & 30 &
\end{tabular}




\begin{tabular}{|c|c|c|c|c|c|c|c|c|c|c|c|c|}
\hline 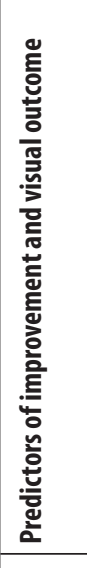 & 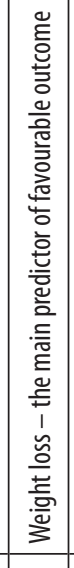 & 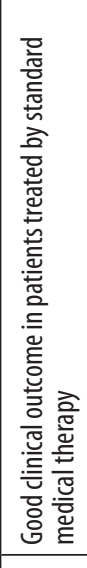 & 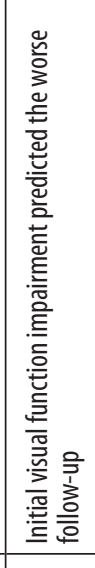 & 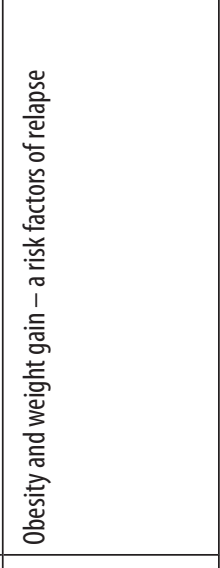 & 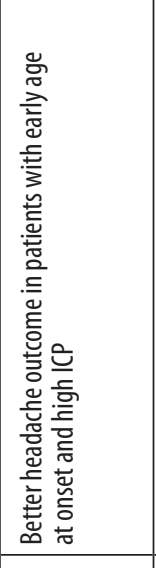 & 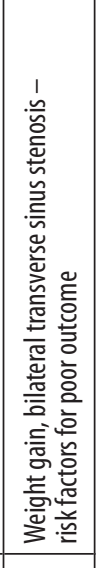 & 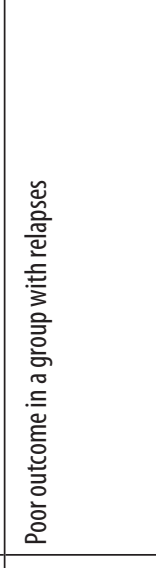 & 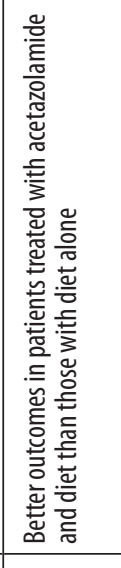 & 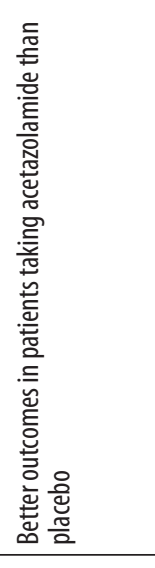 & & 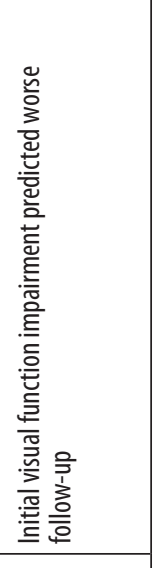 & \\
\hline 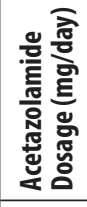 & 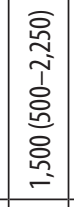 & 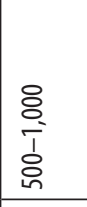 & 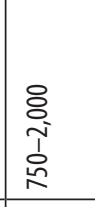 & & 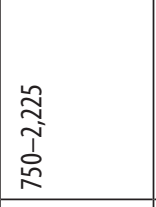 & 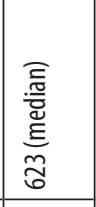 & 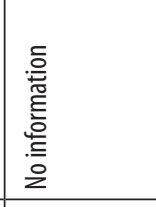 & $\begin{array}{l}\text { O } \\
\vdots \\
1 \\
1 \\
\text { d. }\end{array}$ & 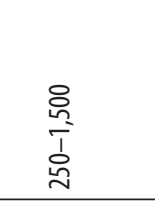 & 0 & 悹 & 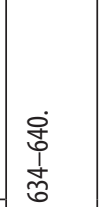 \\
\hline 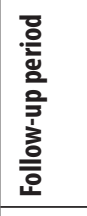 & 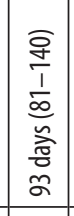 & 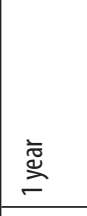 & 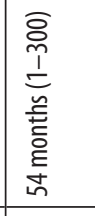 & $\begin{array}{l}\text { 美 } \\
\text { 产 } \\
\infty \\
+1 \\
+1 \\
\dot{\bar{i}} \\
\end{array}$ & $\stackrel{\bar{\Xi}}{\stackrel{一}{\Xi}}$ & $\begin{array}{l}\text { 竟 } \\
\text { 晋 } \\
\end{array}$ & 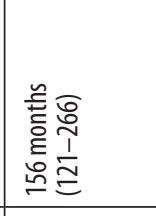 & 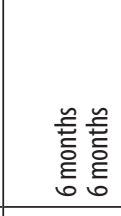 & 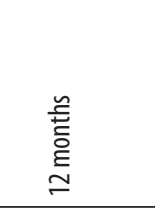 & 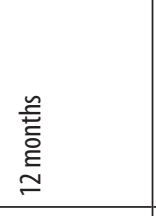 & 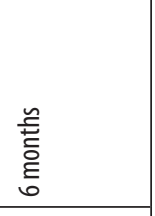 & 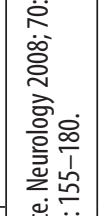 \\
\hline 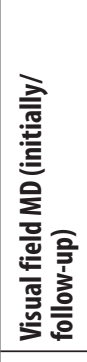 & 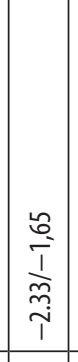 & 1 & 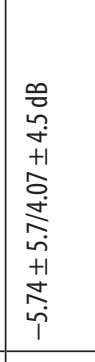 & 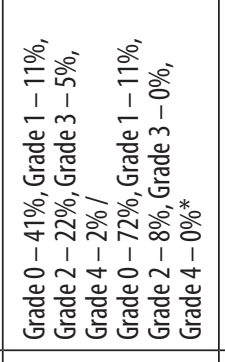 & 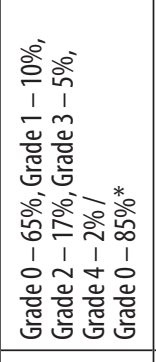 & & 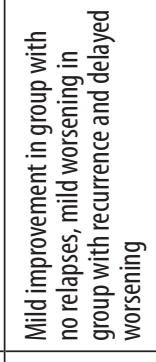 & 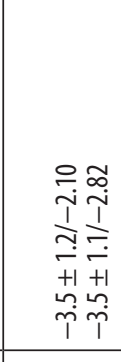 & 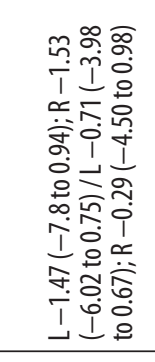 & 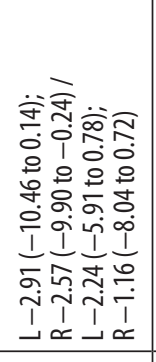 & 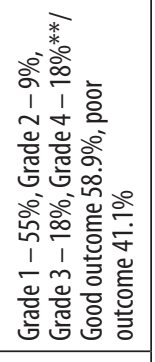 & 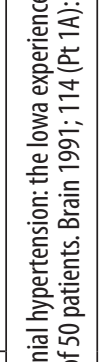 \\
\hline 文 & \begin{tabular}{|l}
$\stackrel{\vec{m}}{\vec{m}}$ \\
$\stackrel{m}{m}$ \\
\end{tabular} & 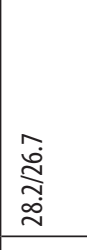 & 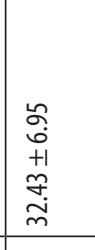 & 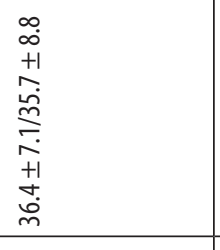 & 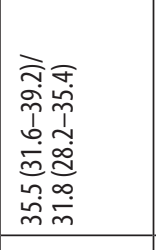 & $\begin{array}{l}\hat{a} \\
+1 \\
+1 \\
\end{array}$ & & 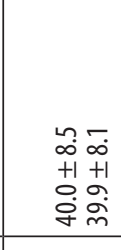 & 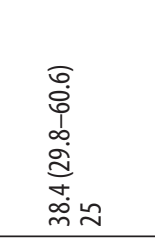 & 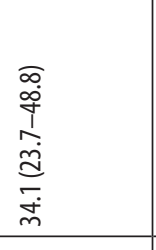 & $\begin{array}{l}n \\
\omega \\
+1 \\
+\infty \\
\sim \\
\sim\end{array}$ & 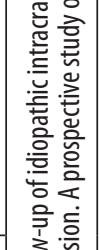 \\
\hline 昰 & 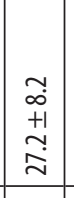 & 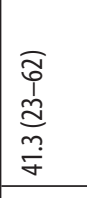 & 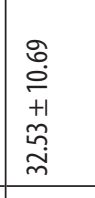 & 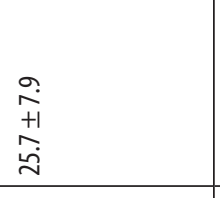 & 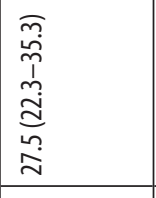 & $\begin{array}{l}\underset{1}{+1} \\
\tilde{m} \\
\end{array}$ & 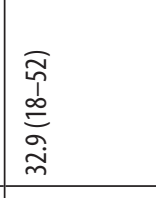 & 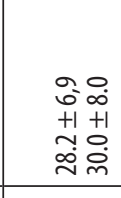 & 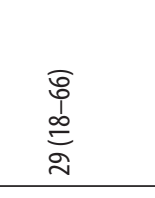 & $\begin{array}{l}\widehat{\widehat{O}} \\
0 \\
\stackrel{0}{\infty} \\
\text { m }\end{array}$ & 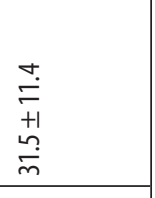 & 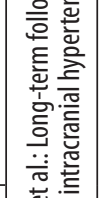 \\
\hline 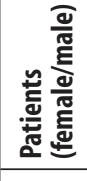 & 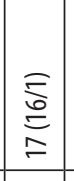 & 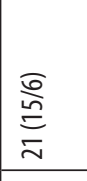 & 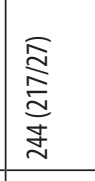 & 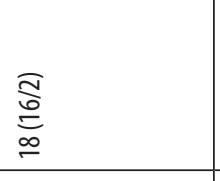 & 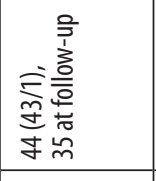 & 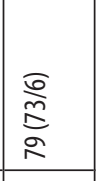 & 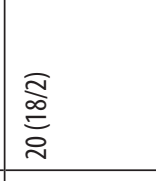 & 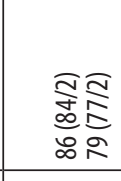 & 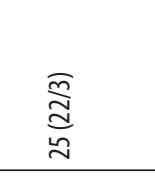 & 虔 & 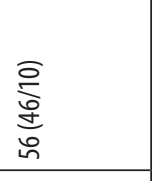 & 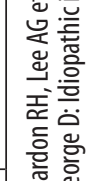 \\
\hline 毫 & 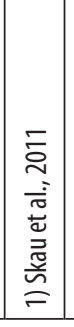 & 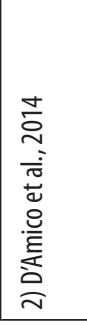 & 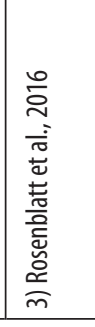 & 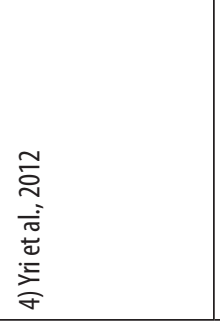 & 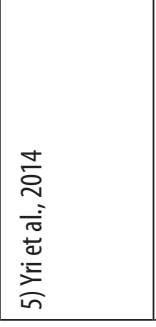 & 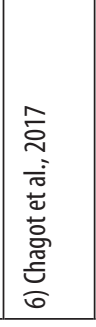 & 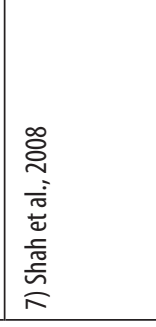 & 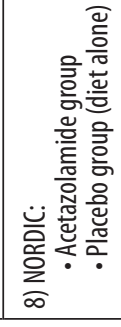 & 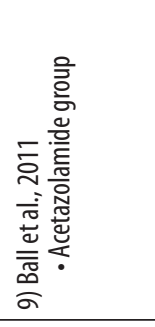 & 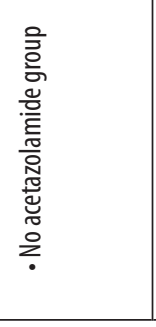 & 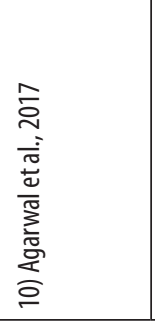 & 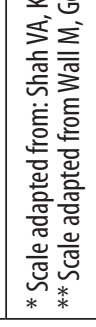 \\
\hline
\end{tabular}


had a disease recurrence. In the study of Skau et al. (2011), weight-loss greater than 3.5\% of BMI was related to a significant reduction in CSF opening pressure after 3 months.

The most recent diagnostic IIH criteria include neuroimaging findings, such as: distention of the perioptic subarachnoid space with the tortuous optic nerve, transverse venous sinus stenosis, empty sella, and flattening of the posterior globe, suggesting $\mathrm{IIH}$, and are useful when the main criteria are not fulfilled (Friedman et al., 2013). In our group, perioptic subarachnoid space distention was seen in 4 patients, transverse venous sinus stenosis in 2 cases and empty sella in one case. Other authors have also observed optic nerve head protrusion, cerebellar tonsillar herniation, meningoceles, and CSF leaks (Bidot et al., 2015). Empty sella was the most often reported sign, but it is also quite often seen in the healthy population (Bidot et al., 2015). When isolated, none of these findings is sensitive or specific enough for IIH (Bidot et al., 2015). Furthermore, some of them, particularly empty sella (D'Amico et al., 2014) and posterior globe flattening, may persist after the resolution of papilloedema and normalisation of ICP, so their presence on MRI does not necessarily indicate an active disease or elevated ICP (Chang et al., 2016).

There was no correlation between the degree of visual parameters (VEP, visual fields) and MRI features of $\mathrm{IIH}$ in the Padhye et al. (2013) group of 35 patients (seen from April 2009 to May 2011). However, the same authors in a longer observation along with Salvay et al. (2014) noticed a significant correlation between the severity of papilloedema and optic nerve head hyperintensity on diffusionweighted MRI.

The VEP examination can be used as a marker of optic nerve damage and as one of the non-invasive tools for assessing intracranial pressure (Rosenberg et al., 2011; Xu et al., 2016), more often in chronic ICP elevations than in acute cases (Kesler et al., 2009). Patients with IIH usually have longer p100 latency (Kesler et al., 2009), which we noted in 2 of our patients upon admission and in 2 during the follow-up visit. Latency prolongation may even precede changes in visual field or acuity (Sørensen et al., 1985). In some studies, a linear relationship between ICP and latency was observed (Sørensen et al., 1985). Patient No. 5 required intensive treatment and had a few recurrences, prolonged latency in this case observed during follow-up visit could be a manifestation of optic nerve damage due to chronic ICP elevation. The same authors noticed a trend towards normalisation of VEP latencies and resolution of pupil oedema, which was not, however, statistically important (patient No. 2 in our group) (Sørensen et al., 1985). Visual field assessment and fundoscopy also seem to be sensitive tools to monitor the disease activity, and appear to be superior to visual acuity (Ball et al., 2011; Rowe and Sarkies, 1998).

Headache was the most common symptom reported during follow-up in all the described patients. In some cases, it of ICP, also in patients without a history of headache before the IIH onset (Yri et al., 2014). Furthermore, in a trial evaluating IIH treatment, there was no significant difference in headache severity between groups receiving active treatment and placebo (Smith and Friedman, 2017). All of this may suggest that some other mechanisms than only elevated ICP could be responsible for headache in $\mathrm{IIH}$ (Friedman et al., 2017). It seems not to be a good parameter to monitor the disease activity.

Migraine is noted in a subset of patients with IIH (Wall et al., 2014). Both these conditions, i.e. chronic migraine and IIH, have a similar clinical picture (including sinus stenosis) and response to topiramate (De Simone and Ranieri, 2015). In the examined group, 2 patients reported such complaints during the control visit. De Simone and Ranieri (2015) concluded that idiopathic intracranial hypertension without papilloedema (IIHWOP) is a risk factor for chronic migraine. Among patients with chronic migraine-like headaches with sinus stenosis in brain MRI and unresponsive to typical medical treatment, IIHWOP should be excluded (De Simone and Ranieri, 2015).

There are some limitations in our study: the lack of CSF pressure details on admission, small number of patients, a retrospective part of the study, examinations conducted only twice (at admission and at the follow-up visit). However, a relatively long observation period and a possibility to revise the diagnosis in some patients are advantages.

Although visual disturbances regressed in most patients, often shortly after starting treatment, and the course of IIH was mild, persistent visual impairment was observed in some cases. We suggest that long-term interdisciplinary follow-up is necessary, particularly in patients with worse prognosis, because delayed deterioration and recurrence may occur even after years of stability (Shah et al., 2008). Patient education is also worthwhile, as BMI is a major yet modifiable risk factor for disease progression and recurrence. Although CSF drainage is not a routine procedure in the literature, it significantly decreased headache and improved vision in a substantial number of our patients.

\section{Conflict of interest}

None. 


\section{References}

Agarwal A, Vibha D, Prasad K et al.: Predictors of poor visual outcome in patients with Idiopathic Intracranial Hypertension (IIH): an ambispective cohort study. Clin Neurol Neurosurg 2017; 159: 13-18.

Ball AK, Howman A, Wheatley K et al.: A randomised controlled trial of treatment for idiopathic intracranial hypertension. J Neurol 2011; 258: 874-881.

Bidot S, Saindane AM, Peragallo JH et al.: Brain imaging in idiopathic intracranial hypertension. J Neuroophthalmol 2015; 35: 400-411.

Bruce BB, Digre KB, McDermott MP et al.; NORDIC Idiopathic Intracranial Hypertension Study Group: Quality of life at 6 months in the Idiopathic Intracranial Hypertension Treatment Trial. Neurology $2016 ; 87$ : 1871-1877.

Bruce BB, Kedar S, Van Stavern GP et al.: Idiopathic intracranial hypertension in men. Neurology 2009; 72: 304-309.

Chagot C, Blonski M, Machu JL et al.: Idiopathic intracranial hypertension: prognostic factors and multidisciplinary management. J Obes 2017; 2017: 5348928.

Chang RO, Marshall BK, Yahyavi N et al.: Neuroimaging features of idiopathic intracranial hypertension persist after resolution of papilloedema. Neuroophthalmology 2016; 40: 165-170.

D’Amico D, Curone M, Erbetta A et al.: Intracranial idiopathic hypertension: 1-year follow-up study. Neurol Sci 2014; 35 Suppl 1: 177-179.

De Simone R, Ranieri A: The role of intracranial hypertension in the chronification of migraine. Neurol Sci 2015; 36 Suppl 1: 23-28.

Friedman D, Quiros PA, Subramanian PS et al.; and the NORDIC IIHTT Study Group: Headache in idiopathic intracranial hypertension: findings from the Idiopathic Intracranial Hypertension Treatment Trial. Headache 2017; 57: 1195-1205.

Friedman DI, Liu GT, Digre KB: Revised diagnostic criteria for the pseudotumor cerebri syndrome in adults and children. Neurology 2013; 81: 1159-1165.

Keltner JL, Johnson CA, Cello KE et al.; NORDIC Idiopathic Intracranial Hypertension Study Group: Baseline visual field findings in the Idiopathic Intracranial Hypertension Treatment Trial (IIHTT). Invest Ophthalmol Vis Sci 2014; 55: 3200-3207.

Kesler A, Vakhapova V, Korczyn AD et al.: Visual evoked potentials in idiopathic intracranial hypertension. Clin Neurol Neurosurg 2009; 111: 433-436.

Ko MW, Chang SC, Ridha MA et al.: Weight gain and recurrence in idiopathic intracranial hypertension: a case-control study. Neurology 2011; 76: 1564-1567.

Mallery RM, Friedman DI, Liu GT: Headache and the pseudotumor cerebri syndrome. Curr Pain Headache Rep 2014; 18: 446.

McGeeney BE, Friedman DI: Pseudotumor cerebri pathophysiology. Headache 2014; 54: 445-458.

NORDIC Idiopathic Intracranial Hypertension Study Group Writing Committee; Wall M, McDermott MP, Kieburtz KD et al.: Effect of acetazolamide on visual function in patients with idiopathic intracranial hypertension and mild visual loss: the Idiopathic Intracranial Hypertension Treatment Trial. JAMA 2014; 311: 1641-1651.

Padhye LV, Van Stavern GP, Sharma A et al.: Association between visual parameters and neuroimaging features of idiopathic intracranial hypertension. J Neurol Sci 2013; 332: 80-85.

Rosenberg JB, Shiloh AL, Savel RH et al.: Non-invasive methods of estimating intracranial pressure. Neurocrit Care 2011; 15: 599-608.

Rosenblatt A, Klein A, Roemer S et al.: Idiopathic intracranial hypertension - a comparison of clinical characteristics between 4 medical centers in different geographic regions of the world. J Neuroophthalmol 2016; 36: 280-284.

Rowe FJ, Sarkies NJ: Assessment of visual function in idiopathic intracranial hypertension: a prospective study. Eye (Lond) 1998; 12: 111-118.

Salvay DM, Padhye LV, Huecker JB et al.: Correlation between papilledema grade and diffusion-weighted magnetic resonance imaging in idiopathic intracranial hypertension. J Neuroophthalmol 2014; 34: 331-335.

Shah VA, Kardon RH, Lee AG et al.: Long-term follow-up of idiopathic intracranial hypertension: the Iowa experience. Neurology 2008; 70: 634-640.

Skau M, Sander B, Milea D et al.: Disease activity in idiopathic intracranial hypertension: a 3-month follow-up study. J Neurol 2011; 258: $277-283$

Smith SV, Friedman DI: The Idiopathic Intracranial Hypertension Treatment Trial: a review of the outcomes. Headache 2017; 57: 1303-1310.

Sørensen PS, Trojaborg W, Gjerris F et al.: Visual evoked potentials in pseudotumor cerebri. Arch Neurol 1985; 42: 150-153.

Wall M, Falardeau J, Fletcher WA et al.; NORDIC Idiopathic Intracranial Hypertension Study Group: Risk factors for poor visual outcome in patients with idiopathic intracranial hypertension. Neurology 2015; 85: 799-805.

Wall M, Johnson CA, Cello KE et al.; NORDIC Idiopathic Intracranial Hypertension Study Group: Visual field outcomes for the Idiopathic Intracranial Hypertension Treatment Trial (IIHTT). Invest Ophthalmol Vis Sci 2016; 57: 805-812.

Wall M, Kupersmith MJ, Kieburtz KD et al.; NORDIC Idiopathic Intracranial Hypertension Study Group: The Idiopathic Intracranial Hypertension Treatment Trial: clinical profile at baseline. JAMA Neurol 2014; 71: 693-701.

$\mathrm{Xu}$ W, Gerety P, Aleman T et al.: Noninvasive methods of detecting increased intracranial pressure. Childs Nerv Syst 2016; 32: 1371-1386.

Yri HM, Rönnbäck C, Wegener M et al.: The course of headache in idiopathic intracranial hypertension: a 12-month prospective follow-up study. Eur J Neurol 2014; 21: 1458-1464.

Yri HM, Wegener M, Sander B et al.: Idiopathic intracranial hypertension is not benign: a long-term outcome study. J Neurol 2012; 259: 886-894. 